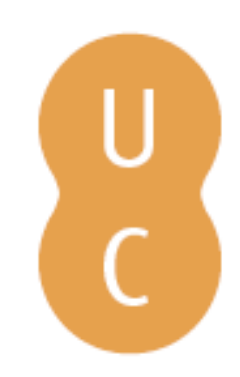

\title{
pombalina
}

\section{WUI, planning and fires in South of France}

Autor(es): $\quad$ Bouillon, Christophe; Ganteaume, Anne; Djazouli, Khalil; Ennesr, Chaimaa

Publicado por: Imprensa da Universidade de Coimbra

URL

persistente: URI:http://hdl.handle.net/10316.2/44614

DOI: $\quad$ DOI:https://doi.org/10.14195/978-989-26-16-506_97

Accessed : $\quad$ 26-Apr-2023 10:01:44

A navegação consulta e descarregamento dos títulos inseridos nas Bibliotecas Digitais UC Digitalis, UC Pombalina e UC Impactum, pressupõem a aceitação plena e sem reservas dos Termos e Condições de Uso destas Bibliotecas Digitais, disponíveis em https://digitalis.uc.pt/pt-pt/termos.

Conforme exposto nos referidos Termos e Condições de Uso, o descarregamento de títulos de acesso restrito requer uma licença válida de autorização devendo o utilizador aceder ao(s) documento(s) a partir de um endereço de IP da instituição detentora da supramencionada licença.

Ao utilizador é apenas permitido o descarregamento para uso pessoal, pelo que o emprego do(s) título(s) descarregado(s) para outro fim, designadamente comercial, carece de autorização do respetivo autor ou editor da obra.

Na medida em que todas as obras da UC Digitalis se encontram protegidas pelo Código do Direito de Autor e Direitos Conexos e demais legislação aplicável, toda a cópia, parcial ou total, deste documento, nos casos em que é legalmente admitida, deverá conter ou fazer-se acompanhar por este aviso.

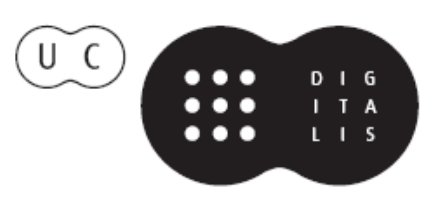




\section{ADVANCES IN}

\section{FOREST FIRE RESEARCH}

\section{8}

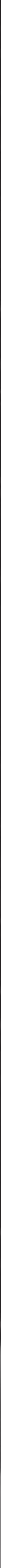




\title{
WUI, Planning and fires in South of France
}

\author{
Christophe Bouillon ${ }^{1 *}$; Anne Ganteaume ${ }^{1}$; Khalil Djazouli ${ }^{2}$, Chaimaa Ennesr ${ }^{3}$ \\ ${ }^{1}$ IRSTEA-RECOVER Mediterranean ecosystems and risks, Aix-en-Provence France, \\ \{christophe.bouillon@irstea.fr*, anne.ganteaume@irstea.fr\} \\ ${ }^{2}$ Université de Nice Sophia-Antipolis, nice, France, \{djazouli.khalil@gmail.com\} \\ ${ }^{3}$ Université de Lille 1, France, \{chaimaa.ennesr@gmail.com\}
}

\begin{abstract}
In France, after a slowdown following the 2008 crisis, there has been an increase in urbanization. Since 2015, in the French Southern region, there has been an increase of urbanization in risk areas. Decision-makers and especially city councilors are greatly involved in the land management because of their capacity in decision-making on diverse topics such as planning and naturals risks. Concerning fire risk, they need to get a correct knowledge of the fire ignitions occurring within their community in order to be able to secure a place, inform the population and ensure fire prevention

Urban sprawl has progressively gained land classified in "NB" (large building plots in natural or agricultural areas) or abandoned by agricultural activities, by creating an interface zone where habitats and natural spaces are intertwined. The coexistence of spaces and continuities often unkempt, with dense vegetation, creates the conditions for the outbreak and the spread of fires in a complex area, difficult to defend. (In France, 25000 ha / year are urbanized mainly at the expense of agricultural, natural and forest areas).

In this context, this study aims at providing decision-makers with all useful information about fire ignitions and their specialization in the community, especially in the wildland-urban interfaces taking into account the planning and the mandatory brush-clearing area and taking the département de l'Hérault as the study area.

The studies and results proposed in the paper are a part of a Natural Risk program founded by the French Ministry of Environment. It will give an analysis and information to stakeholders concerning relationships between land planning, WUI and wildfires in their municipality. The aim is to provide knowledge of habitat vulnerability to wildfire and the opportunity of a careful consideration of new urbanization zones. The high demands of land along the Mediterranean coast and hinterland have issued a large extension of urban areas near natural or rural land, creating new WUI at risk.

A spatial analysis of the points of departure of fire was carried out with the taking into account of various aspects: fire ignitions and interfaces types, fire ignitions and land use, fire ignitions zoning in planning documents.

We try to find relationships between fire ignition location and planning document according to the LULC in the study area in the context of WUI.

The results confirm a strong relationship between WUI and fire ignition. In the WUI the fire density is three times higher than outside.

Considering this, a decision support tool was developed to help the stakeholders to simulate the new WUI configuration for new buildings and development zone in connection with the existing WUI.
\end{abstract}

Keywords: Wildfire, wildland urban interface, planning, fire risk, decision making

\section{Introduction}

The studies and results proposed in this paper are a part of a Natural risk program founded by the French Ministry of Environment. It will give an analysis and information to stakeholders concerning relationships between land planning, WUI and wildfires in their municipality. The aim is to provide knowledge of habitat vulnerability to wildfire and a careful consideration of the proposed extension of urbanization zones. The high demands of land along the Mediterranean coast and hinterland have 
created a large extension of urban areas near natural or rural land creating new WUI at risk.

In France, after a slowdown following the 2008 crisis, there has been an increase in urbanization. Since 2015, in the French Southern region, there has been an increase in urbanized zones in risk areas with a significant increase in population and an uncontrolled consumption of space. This is the case for peri-urban areas in the conurbations and in the Atlantic and Mediterranean littoral zones. On the Mediterranean coast, we can perceive a saturation effect: The consumption of space moves in the municipalities of the hinterland. (25000 ha / year are urbanized mainly at the expense of agricultural, natural and forest areas.)

Decision-makers and especially the city councilors are greatly involved in the land management because of their capacity in decision-making on different topics such as planning and naturals risks. Concerning fire risk, they need to get a correct knowledge of the fire ignitions occurring within their community in order to be able to secure a place, to inform people and ensure fire-prevention.

In this context, this study aims at providing the decision-makers with all useful information about the fire ignitions and their spatialization in the community, especially in the wildland-urban interfaces but also about the land-cover and the mandatory brush-clearing area, taking the département de l'Hérault as the study area.

The ancient planning document - the land use plan (POS) in force between 1967 and 2017 included areas allowing the construction on large plots, coded "NB" (large building plots in natural or agricultural areas) which led to a dissemination of houses located in the forest or in their approach. The law Alur (Loi no 2014-366 du 24 mars 2014) has planned the end of the POS and NB areas on March 27, 2017. It has been replaced by the local urban plan (PLU), this is the major planning document in use in most of the municipalities. It includes rules on the prevention of forest fires, clearing and in the case of a fire risk prevention plan, the specific urban planning rules applicable to the concerned areas. Changes in land use, especially in agricultural abandonment, create an interface zone where habitats and natural spaces are intertwined. The coexistence of spaces and continuities often unkempt and with dense vegetation creates the conditions for the outbreak and the spread of fires, in a complex area difficult to defend. The final purpose of this study consists in providing them with a decision-making support tool when they come to produce or review the documents. This tool will take into account all the parameters inherent in the fire-risk that are pointed out in this work. It will also help the decision-makers to understand better the impact of forest fires in terms of vulnerability and gauge the greater risk in urban development zones.

\section{Materials}

\subsection{Study zone}

The chosen study area (Figure 1) is the département de l'Hérault, an administrative territory, in the Occitanie Region. This zone is located in the south of France near the Mediterranean Sea and with Montpellier, a major city and urban area of 600000 people.

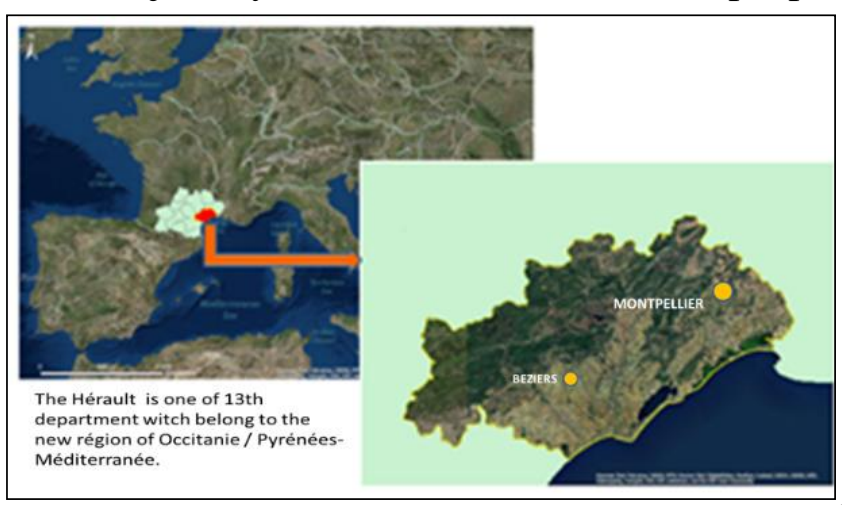

Figure 1 - Study zone location- France

Advances in Forest Fire Research 2018 - Page 879 
This département is facing a profound change in its environment. A strong dynamics of urbanization is developing in this area. The new urbanized areas are progressing in areas that are changing and sensitive to forest fires. The areas concerned are in particular areas abandoned by agriculture, especially old vineyards.

"In addition these areas belong to the top most average of fire prone areas located in the South of France and among the highest fire ignition numbers (Figure 2).

A special feature is the increase of so called "AFERPU - autres feux de l'espace rural et péri urbain", also named peri-urban fires. If generally this kind of fire is smaller than forest fire it can be very dangerous for the people and belongings as it spreads in the WUI areas. Sometimes this type of fire can threaten larger natural or forested areas and become a forest fire.

\subsection{Data and softwares}

The choice of this study zone was directed by the availability of updated data. The stakeholders of Direction départementale des Territoires et de la Mer du département de l'Hérault (DDTM 34) concerned by forest fire, managed a fire database with detailed facts and linked to the official forest fire database for the French Mediterranean region "Promethée". It contains detailed information on all fires between 2005 and 2014, including the geographical location of fire points and is an essential source of information for this study

The advantage of the choosen study area is the availabililty of up-to-date databases, especially concerning fires. Fot his study, we use :

- Land cover - SIG L-R, 2006 from OpenIG Occitanie Pyrénées

- Buildings BD TOPO® v2.1 2011 révised 2013, 1m precision from Institut National de l'Information Géographique et Forestière

- Clearing law zone from DDTM 34

- Planning documents géographiques from Adélie database, 2015

- Ignition points, burnt areas and causes from Adélie and Prométhée databases, 2015

All the data were georeferenced and processed with ArcGis, the statistical calculations with Statgraphics.

For the ignition points, 5 main classes of causes were used : (Table 1) : natural, accidental from installations, volontary, unintentionnal professionnal works and unintentionnal private owners works.

Table 1 - Causes of fire

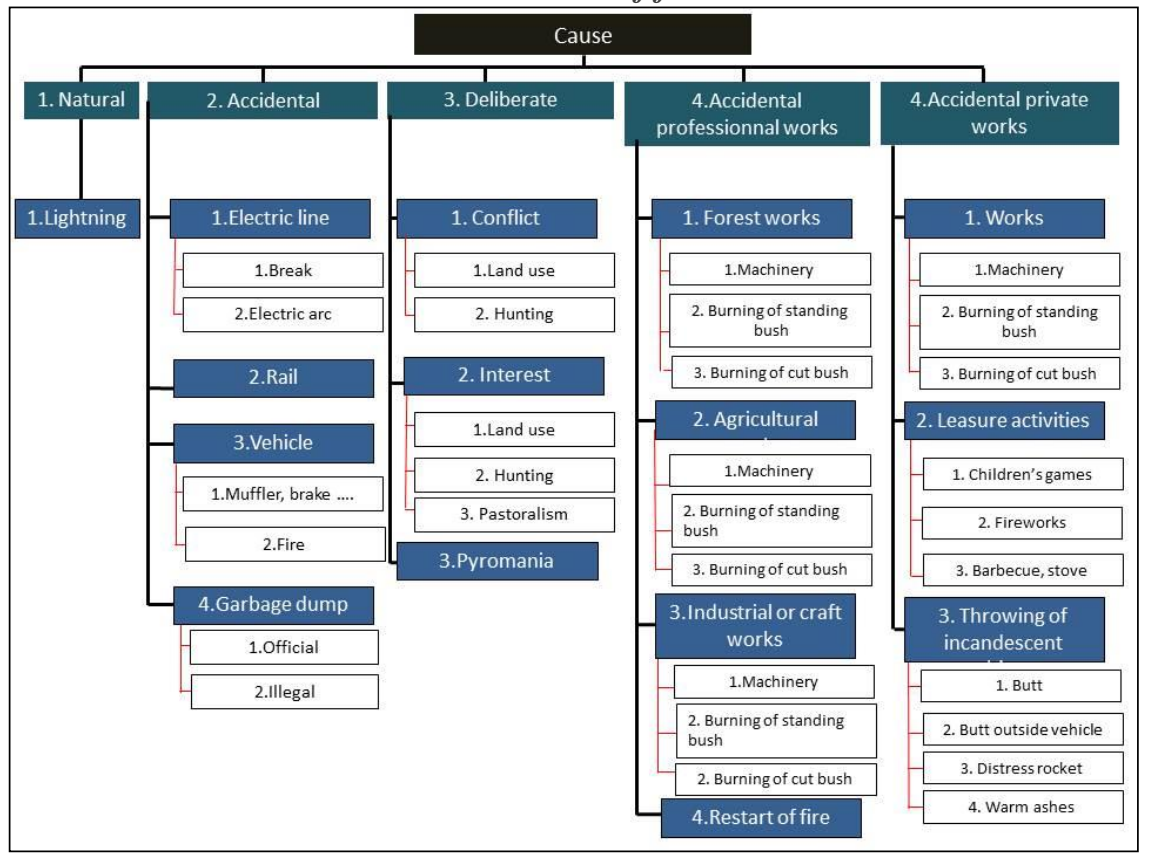

Advances in Forest Fire Research 2018 - Page 880 


\section{Methods}

\subsection{Fire definitions}

In the French fire databases, these main types of fires are recorded.

Forest fire, scrubland, maquis and moors : Fire that has reached forests, moors, scrubland or maquis with an area of at least one hectare in one piece (and regardless of the area covered). Nota Bene: The term "reaches" implies that at least a part of the shrub or tree stage has been destroyed.

Other fires (AFERPU): fires that concern peri-urban and rural areas and that do not threaten the forest - Fires of the rural and peri-urban space, or fire of vegetation not belonging to the preceding category. Six types are identified: fires in beds of less than 1 ha, linear afforestation fires, grass fires, other agricultural fires, garbage dumps, other.

\subsection{WUI mapping}

The mapping of WUI uses the method developed by Irstea (Lampin 2009) and the software developed for an automated calculation of maps (Lampin \& Bouillon 2011). Based on housing configuration (4 classes) and vegetation aggregation (3 classes), this method creates a 12 class WUI. The input data are the buildings and the land use or vegetation aggregation index from aerial or satellital image when available.

This method is used in different studies across Europe (FUME European program). The land use land cover (LULC) study was made with the SIG LR LULC data from the Occitanie Region.

\subsection{Analysis process}

The digital planning documents (from DDTM 34), were harmonized in 5 classes representing the major groups of zoning (Natural, Agricultural, Urban, to be Urbanized.)

Then a Spatial analysis of ignition fire was carried out with the taking into account of various aspects: fire ignitions and types of interfaces, fire ignitions and types of land use, fire ignitions and types of zoning in planning documents.

\section{Results}

The study area is part of a the former Languedoc-Roussillon region concerned with forest fires in France. The higher risk is located in the southerm part of the country along the Mediterranean coast and with hinterland areas and the Landes forest in the South-West of the country. (Figure 2)

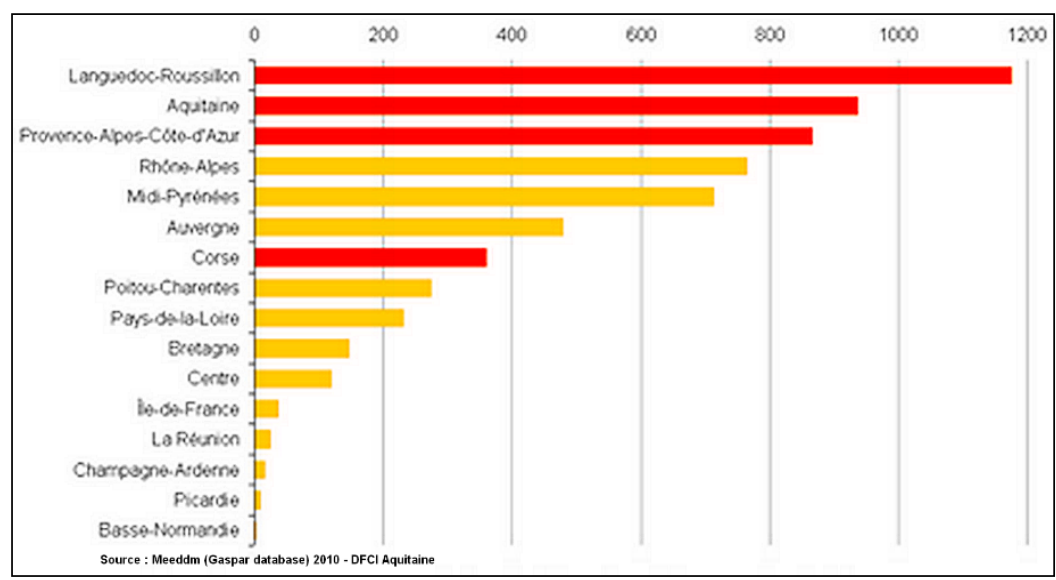

Figure 2 - Municipalities by regions exposed to forest fire risf - France

Regarding the forest fire risks, the main concerned public policies are : the planning policies, the prevention policy and other national policies like agricultural ones. 
The main rules of urban planning in France have been based since 2000 upon the plan local d'urbanisme (PLU). It is the main planning document in use in municipalities. In some other cases, the old plan d'occupation des sols (POS) or carte communale (CC) remain. If no local plan or document exists, the national rules of planning (RNU) are applied.

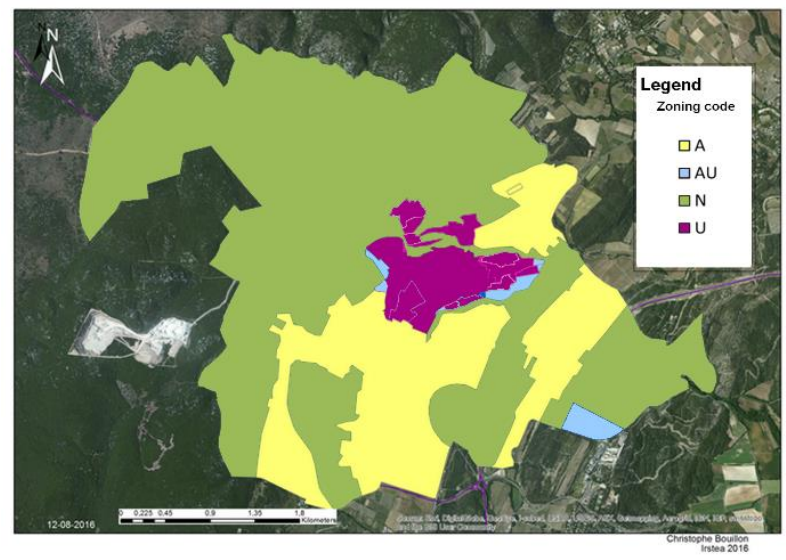

Figure 3 - Planning zones- Les Matelles municipality

The zoning is composed of 4 major categories (Figure 1)

- $\quad \mathrm{U}:$ urban area

- $\quad \mathrm{N}$ : natural area

- A : agricultural area

- $\quad$ AU : to be constructed area

For each zone, some rules were set up such as : construction distances, height, window types and the constructible area for each lot with a soil occupation coefficient (COS)

\subsection{Ignition points and types of interfaces}

The study is based upon the localization of the starting points of fire in the WUI.

The WUI covers $23.52 \%$ of the total area of the department of Hérault. The majority of the interfaces belongs to the isolated housing type with $35 \%$, followed by very dense with $30 \%$. housing type (Table 2)

Table 2 - Types of interfaces in the study area

\begin{tabular}{|l|c|l|}
\hline Housing type & Area (ha) & $\mathbf{( \% )}$ \\
\hline Isolated & 51729 & $35 \%$ \\
\hline Scattered & 36144 & $25 \%$ \\
\hline Dense & 14672 & $10 \%$ \\
\hline Very dense & 44061 & $30 \%$ \\
\hline Total & 146606 & $100 \%$ \\
\hline
\end{tabular}

As a matter of fact, the spatial organization of buildings in the Hérault is very dense along the coastline, particularly in the municipalities of Montpellier and Béziers which are the most populated area. The housing types mentioned bove are also observed near the urban core of other most important municipalities. The further we get off the coast, the more the urban fabric becomes loose, and we find more isolated habitat. The scattered habitat represents $25 \%$ of the interfaces and it is localized on the periphery of the aforementioned urban cores and sometimes operates the junction between the two areas of dense housing. It should be noted that the dense structure covers only $10 \%$ of the surface, and is mostly an extension of very dense areas. 
The ratio between the surface of the WUI and the number of ignition points is very significant as $30 \%$ of fires starts in these areas.(Figure 5)

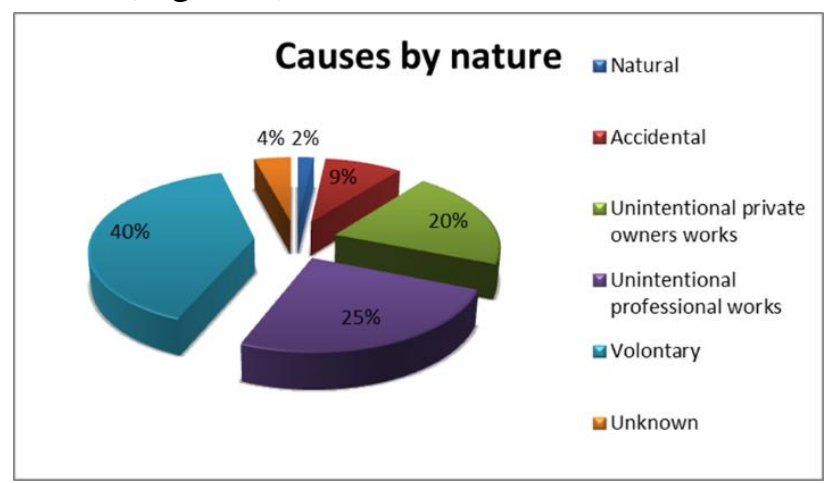

Figure 5 - Fire causes in the study area

The WUI with isolated housing classes are most at risk of fire. It is due to the layout of space with large areas which increases the degree of fire risk because of vegetation not managed.

Table 3 - Causes of fire with simplified classification (K Djazouli, source Adelie 2015)

\begin{tabular}{|l|l|l|}
\hline Nature of cause & Nb & Burnt area (ha) \\
\hline Natural & 31 & 4 \\
\hline Accidental & 148 & 890 \\
\hline Unintenional private owners works & 346 & 1305 \\
\hline Unintentional professional works & 424 & 2232 \\
\hline Volontary & 669 & 6131 \\
\hline Unknown & 70 & 240 \\
\hline Total & 1688 & 10802 \\
\hline
\end{tabular}

Dense and very dense interfaces are very rarely affected by fires. Groupings of structures act as fuel cuts in case of a fire starting. The results, presented in the tables, show that out of the 1688 ignition points, $40 \%$ of fire causes are due to arsonism, followed by unintended causes related to professional work $(25 \%)$, as well as unintentional causes related to specific work at $20 \%$. To a lesser degree, the accidental and natural causes also represent respectively $9 \%$ and $2 \%$. To specify that, only a minimal part of the causes unidentified is $4 \%$ of the total data.

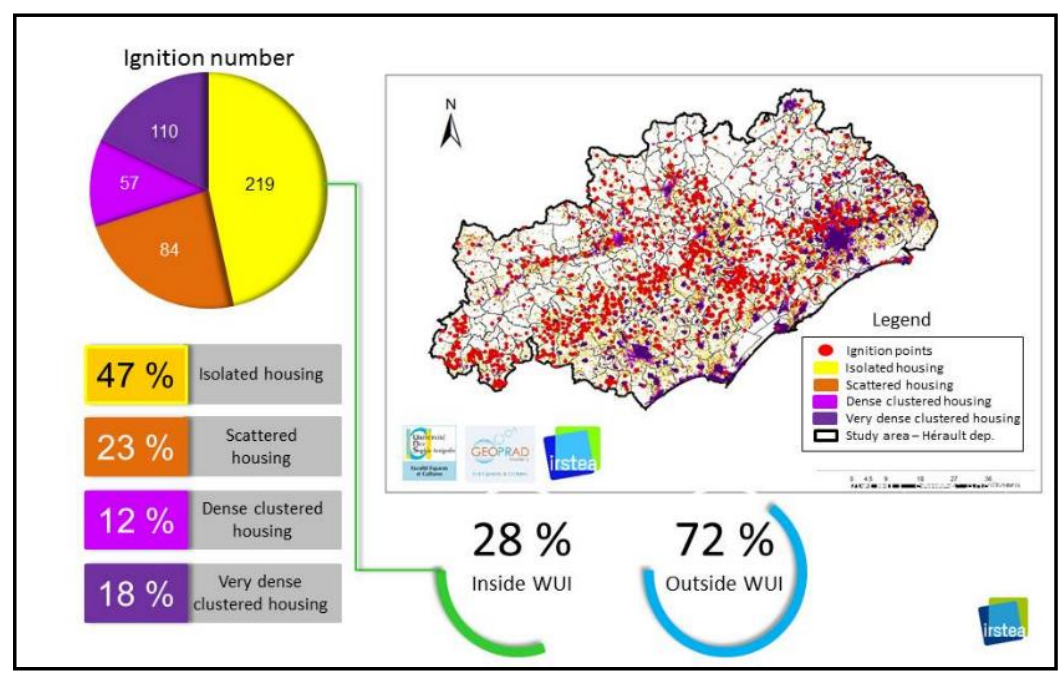

Figure 4 - Causes of fire starting in the interfaces 
Table 4 - Fire starting number in interface zone surface (communal data)

\begin{tabular}{|l|l|l|}
\hline \multicolumn{1}{|c|}{ Housing type } & $\%$ & Ignition points \\
\hline Isolated & $46 \%$ & 219 \\
\hline Scattered & $24 \%$ & 110 \\
\hline Dense & $12 \%$ & 57 \\
\hline Very dense & $18 \%$ & 84 \\
\hline Ignitions points in WUI & 470 \\
\hline Outside WUI & 1218 \\
\hline
\end{tabular}

\subsection{Ignition points and types of land use}

The following analysis was made by crossing the ignition point locations according to the land use with WUI types. We can see that within artificialized territories, outbreaks are essentially born in discontinuous urban fabric with 41 out of 64 fire ignitions across the artificialised territories. It should also be noted that within the scattered housing buildings, there are also 18 fire outbreaks.

Table 5 - Ignition points and Land Cover (Khakil Djazouli, DDTM 34)

\begin{tabular}{|c|c|c|c|}
\hline \multicolumn{2}{|r|}{ Land cover } & Ignitions & $\%$ \\
\hline \multirow{5}{*}{$\begin{array}{l}\text { Territoires } \\
\text { Artificialisés }\end{array}$} & Discontinuous urban fabric & 41 & $7 \%$ \\
\hline & Scattered housings & 18 & $4 \%$ \\
\hline & Industrial & 2 & $0,5 \%$ \\
\hline & Consruction zone & 1 & $0,5 \%$ \\
\hline & Leasure and sports facilities & 2 & $0,5 \%$ \\
\hline \multirow{7}{*}{$\begin{array}{l}\text { Agriculture et } \\
\text { végétation éparse }\end{array}$} & Arable lands & 10 & $2 \%$ \\
\hline & Vineyards & 120 & $25 \%$ \\
\hline & Olive trees & 2 & $0,5 \%$ \\
\hline & Complex agricultural plots systems & 17 & $4 \%$ \\
\hline & Agriculture and sparse natural vegetation & 1 & $0,5 \%$ \\
\hline & Moors & 4 & $1 \%$ \\
\hline & Sparse vegetation & 14 & $3 \%$ \\
\hline \multirow{6}{*}{$\begin{array}{l}\text { Forêts et } \\
\text { Végétation dense }\end{array}$} & Deciduous forests & 36 & $8 \%$ \\
\hline & Coniferous forests & 59 & $13 \%$ \\
\hline & Mixed forests & 1 & $0,5 \%$ \\
\hline & Natural pastures & 8 & $2 \%$ \\
\hline & Shrublands & 50 & $10,5 \%$ \\
\hline & Forest and evoluting shrubland & 81 & $16 \%$ \\
\hline Divers & & 3 & $1 \%$ \\
\hline TOTAL & & 470 & $100 \%$ \\
\hline
\end{tabular}

Within farmland, with sparse vegetation, nearly three quarters of fire ignition start in wineyards. Finally, at the level of dense vegetation types, there are 81 fire ignitions in the forest and shrubby vegetation, followed by 59 fire outbreaks in coniferous forests and 50 fire ignitions in shrublands (Table 5)

\subsection{Ignition points and planning documents}

In Hérault (343 municipalities), 129 communes, nearly $40 \%$ of the municipalities in the department, adopted the Local Urban Plan as a document. However, 123 municipalities have retained 
the Land Use Plan.19 municipalities, nearly 5\% of municipalities, have the Communal Map and 20\% refer to the National Urban Planning Regulation. Finally, 4 communes turned to the Local Urban Plan.

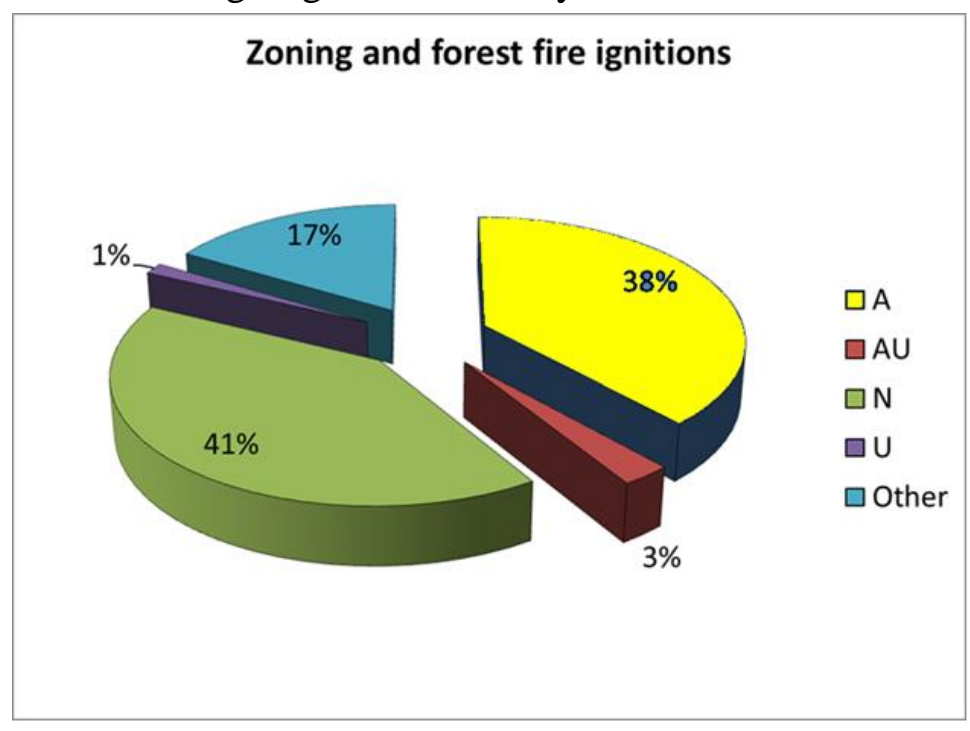

Figure 6 - Fire ignition and planning zones

We can see that the majority of ignition points are located in natural areas (Figure 6) with 693 points, followed by agricultural areas which were affected by 647 outbreaks. Thus, the areas to be urbanized and the urban areas, recorded respectively only 46 and 24 fire ignition points. It should be noted that 278 points are not included in the new zoning, because the zoning types were not available for certain municipalities with RNU.

In a part of the research, we try to find relationships between fire ignition location and planning document according to the LULC, in the study área, in the context of WUI.

The results confirm the relationship between WUI and fire ignition. In the WUI, the fire density is three times higher than outside.

Other types of fire summed up by municipalities (Figure 7)show a correlation between the WUI area and the number of peri-urban and rural fires and between AFERPU fires and AU zones (to be constructed area).

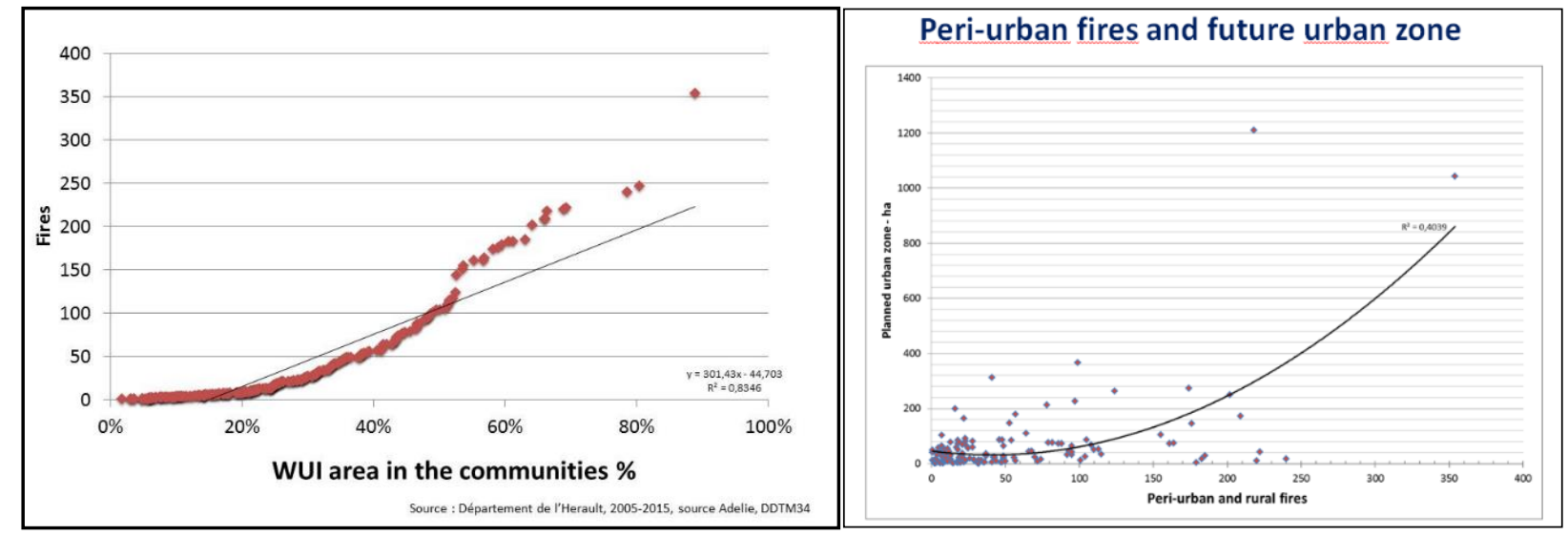

Figure 7 - Fire ignition, WUI and planning zones 


\section{Discussion}

\subsection{Planning and fire risk: the spreading of urbanization and WUIs}

The ancient planning document - the land use plan (POS) in force between 1967 and 2017- included areas allowing the construction on large plots, coded "NB" which led to a dissemination of houses located in the forest or in their approach. The law Alur (Loi no 2014-366 du 24 mars 2014) has planned the end of the POS and NB areas on March 27, 2017.

The consequences of old « NB » zoning are that they allowed constructions in agricultural and forested area, with large construction plots 2000 to $30000 \mathrm{~m}^{2}$. These areas have been difficult to manage and comply with forest fire prevention. Their locations have increased fire ignition risk because of human activities within natural areas or near them. The « NB » zoning also contributes to the creation of WUI zones with complex organizations difficult to defend in case of fire. The possibility of dividing these properties into several lots has reinforced the phenomenon. This type of zoning was cancelled by law in 2017, but these areas often keep a lot of burnable fuel.

The numerous fire ignitions in vineyards are surprising and an explanation is to be found. We found it thanks to the many readings. The results of these facts were confirmed by other studies concerning the same areas and topics. The CEREMA- (Centre d'études et d'expertises sur les risques, l'environnement, la mobilité et l'aménagement) observatory reports some statistics about soil consumption in France and FranceAgriMer studies the consequences of the uprooting program in Languedoc-Roussillon former region. We found facts and figures which confirm our results and give us some clues about the WUI and fire issues.

The extension of urbanization has been a continuous process for many years. Despite the SRULaw (Solidarity and Urban Renewal) of 13 December 2000, and despite a careful and thrifty management of the territory, most of the country has been affected by a consumption of land for urbanization.

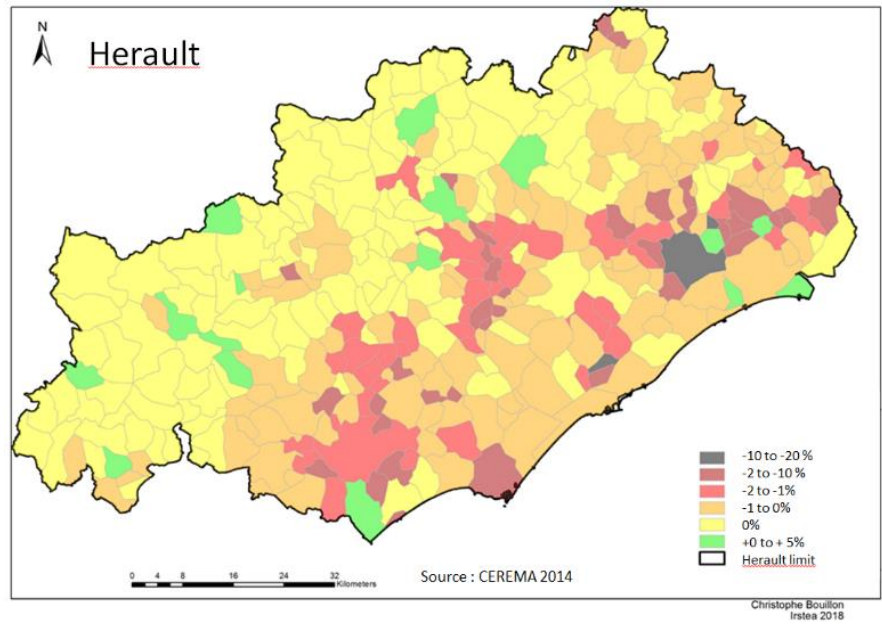

Figure 8 - Evolution of natural, agricultural or forested land in Hérault - 2006-2013 - Source CEREMA

The main land consumption is for individual housings and infrastructures. These extensions were made on agricultural, natural or forested lands. (Agreste, 2004)

\subsection{Impact of State agricultural policies}

Regarding agricultural policies and the impacts in the study area, new fire prone areas were created. The aim of this policy was to increase the vineyard quality, to improve the wine European market and replace low quality wines with better ones. 


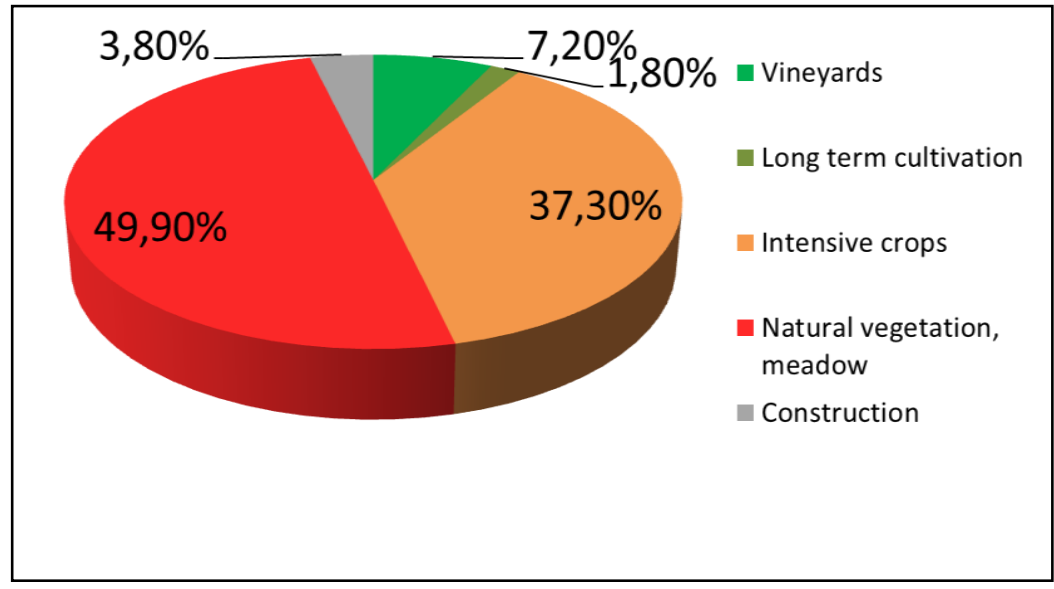

Figure 3 - Land use of uprooted wineyards in th Hérault in 2014-Source FranceAgriMer

From 1980 to 2011, the Hérault department faced the uprooting of half of its vineyards, within the framework of the Permanent Abandonment Premiums, an European structural measure aimed at cleaning up the European wine market. This led to profound changes in the landscapes of the Hérault territories, with a change in destination of the uprooted plots and a disruption of the balance between production and vineyard landscapes. The question of the future of the uprooted vine lands is acute, resulting in the mobilization of local actors on different scales. They take public policies intended to overcome land abandonment and to accompany changes in rural landscapes affected by the uprooting.

\section{Conclusion}

The risk of fire is greater in the WUI and additional observations can be made on the current LULC in these fire-sensitive areas.

In the département de l'Hérault prone to important changes, the zoning of urban areas (U) are still occupied at $21 \%$ by areas with agricultural land use; these areas are sometimes abandoned with brush vegetation and may change into forested areas.

Areas to be urbanized (coded AU) have a land-use composition with potentially significant combustible surfaces. The study shows that $45 \%$ are classified as natural areas while $41 \%$ are classified as agricultural areas, sometimes abandoned.

These unkempt "transitional" areas are conducive to fire-outbreaks and spreading. This state of awaiting projects, construction, infrastructure or other activities, can last for a long time.

The zoning-modification (local urban plan, etc.) has sometimes consequences on the vulnerability of the buildings, infrastructures, networks which are at stake. This is particularly true when new building zones are created. The addition of new buildings leads to the creation of new areas of interfaces and therefore increases the vulnerability of the facilities.

Sometimes an "AU" zone at the edge of an interface already present, and in contact with natural vegetation increases risk. The future area to be protected will increase the interface area subject to legal clearing requirements too. The potential risk is twofold: the natural area may be affected by a fire-outbreak in this new interface zone, and conversely a fire propagating in the natural area may threaten the future buildings of the new zone.

In other cases the AU zones are under development, which can last several years.

The formerly visible agricultural areas are sometimes abandoned pending projects (building plots). Therefore some lands abandoned by agriculture are particularly sensitive to fire.

On the outskirts of larger towns, the colonization of agricultural lands by the progression of the AU zones, creates unkempt islands near existing buildings and is the source of many fires. 
A recent study of abandonned agriculture land reinforces our study, as the sampling of ancien agricultural zones show the state of abandonment in the study area.

The different public policies, from the municipal level to a national one, could have consequences on the fire risk and not take them into account.

\section{References}

Arnal, C., Laurens, L., Soulard, C.,2013, The landscape mutations generated by the uprooting of vineyard, a vector for the mobilization of local actors in the Herault department [Article@Les mutations paysagères engendrées par l'arrachage viticole, un vecteur de mobilisation des acteurs territoriaux dans l'Hérault] (2013) Mediterranee, 120 (1), pp. 49-58.

Bouillon, C., Fernández Ramiro M.M. Fierro García B, Sirca C.,Long-Fournel M, Casula F., Pellizaro, G., Arca, B., Maillé, E., Bellet, A., Pugnet, L., Vila-Molina, B., Ferrara, R., Pintus, G.V. - 2013. FUME (Forest fires under climate, social and economic changes in Europe, the Mediterranean and other fire-affected areas of the world ) European Program Déliverable D 1.1.5. The RUI and fire risk Analysis and mapping of the spatial and temporal changes of the RUI on local and regional scales and of fire occurrence Aix-en-Provence 148

CEREMA, 2016, La consommation d'espaces et ses déterminants d'après les Fichiers fonciers dela DGFiP, Analyse et état des lieux au 1er janvier 2015 Direction territoriale Nord-Picardie : 2, rue de Bruxelles - CS 20275 - 59019 Lille Cedex, 41p.

Costantino Sirca, Franco Casula, Christophe Bouillon, Belen Fierro García , Monica Maria Fernandez Ramiro, Beatriz Vila Molina, Donatella Spano , 2017, A wildfire risk oriented GIS tool for mapping Rural-Urban Interfaces, Environmental Modelling \& Software 94 (2017) 36-47 https://doi.org/10.1016/j.envsoft.2017.03.024

FranceAgriMer-LR, 2012, Enquête sur le devenir de 500 parcelles arrachées primés PAD entre $2005 / 2006$ et $2010 / 2011$

Lampin-Maillet \& C., Bouillon C. , 2011, WUImap: a software tool for mapping rural-urban interfaces at a large scale over a large area in Mediterranean European context. Journal of Environmental Science and Engineering, 5, 2011-4

Lampin-Maillet, 2009, Caractérisation de la relation entre orgzniqtion spatiale d'un territoire et risque d'incendie : le cas des interfaces habitat-foret du sud de la fgrance, thèse en géographie, Université de Provence, Aix-Marseille, 396p.

Ministère de l'agriculture et de la pêche, Agreste, 2009, "La maison individuelle grignote dles espaces naturels, Agrest Primeur n]219, janvier 2009,

Ministère de l'Agriculture, L'utilisation du territoire en 2014, Agreste chiffres et donnes Agriculture $\mathrm{n}^{\circ} 229$

Ministere de l'agriculture de l'alimentation, de la pêche, de la ruralité et de l'aménagement du territoire; Ministère de l'intérieur de l'outre-mer, des collectivités territoriales et de l'immigation, 1973-2018 , Prométhée (C), base de données officielle pour les incendies de forêt dans la zone méditerranéenne française, $v 1.0 .39$ 